\title{
Review regarding defrosting methods for refrigeration and heat pump systems
}

\author{
Jamal Al Douri ${ }^{1,3}$, Kamel S. Hmood ${ }^{1,2}$, Valentin Apostol ${ }^{1}$, Horatiu Pop ${ }^{1 *}$, Saleh J. \\ Alqaisy $^{1,3}$ and Elena Beatrice Ibrean ${ }^{1}$ \\ 1Dept. of Applied Thermodynamics, Engines, Thermal and Refrigeration Equipment, University \\ POLITEHNICA of Bucharest, Romania \\ 2 University of BABYLON, Iraq \\ 3 University of TECHNOLOGY, Iraq
}

\begin{abstract}
The paper presents a literature review regarding defrosting methods for household refrigeration and heat pumps. The literature review covers the period between 2008 and 2020. A number of 61 papers have been studied. The literature review was conducted by dividing the defrost methods into passive and active. Passive methods involve surface coating and off-cycle. The active defrost methods involve reverse cycle, ultrasonic vibration, hot-gas defrost, electric heating and hot fluid. Surface coating and ultrasonic vibration are recent defrost methods proposed in the literature. Also, recently, phase change materials have been used in household refrigerators to improve their efficiency. This is a topic that needs further investigation and is a subject of interest as it can lead to lower energy consumption during defrost cycles. From the present study, the research direction regarding the use of PCMs in defrost cycles can be highlighted.
\end{abstract}

Keywords: defrost, PCM, refrigeration systems, heat pumps

\section{Introduction}

Vapour compression refrigeration systems (VCRs) are the most widely used technical solution in the field of artificial cooling. Frost accumulation on the evaporator surface is an important problem. Frost appears when the moist air comes into contact with the evaporator surface having a temperature lower than $0^{\circ} \mathrm{C}$ [1]. When frost accumulates on the evaporator surface, it acts as a thermal insulator leading to lower performance of the refrigeration system and in consequence, to higher energy consumption [2, 3]. To avoid the low performance of the refrigeration system, the accumulated frost needs to be removed. The same observations can be applied in the case of heat pumps. In this context, the present work presents a literature review regarding defrosting methods used in VCRs and heat pumps. In this work, a defrost method refers to any method that prevents frost formation and also to frost removal after formation.

Section 2 of the paper presents the most widely used passive and active defrost methods, Section 3 shortly presents phase change materials (PCMs), Section 4 presents the application of PCMs in household refrigeration systems and discusses the possibility to use PCMs in defrosting cycles. Conclusions are presented in Section 5.

The literature review covers the period between 2008 and 2020. A number of 61 papers have been studied. The literature review was conducted by dividing the defrost methods into passive and active. For each method, the authors have struggled to cover the available

\footnotetext{
* Corresponding author:horatiu.pop@upb.ro
} 
scientific literature and present the conducted work in a synthetic and easy to follow manner.

\section{Passive and active defrosting methods}

There are two main types of defrosting methods: passive and active. In this section, each of the two defrosting methods will be approached and discussed.

\subsection{Passive defrosting}

A passive defrost method is a method that does not involve direct energy consumption during the defrost process. The most commonly used passive defrost methods are surface coating and off-cycle [3].

\subsubsection{Surface coating}

In recent years, with the advance of material technology, evaporator surface coating has become a simpler and more effective anti-frosting technology. Wang et al [4] investigated three types of evaporator fins namely, hydrophilic, bare and superhydrophobic, as shown in Fig.1. They concluded that the superhydrophobic fin outperforms the hydrophilic and bare fins in terms of slowing droplet condensation time. Cai et al [5] investigated frost growth on hydrophobic and bare surfaces. Results indicated that hydrophobic surfaces can delay the growth of the frost layer.

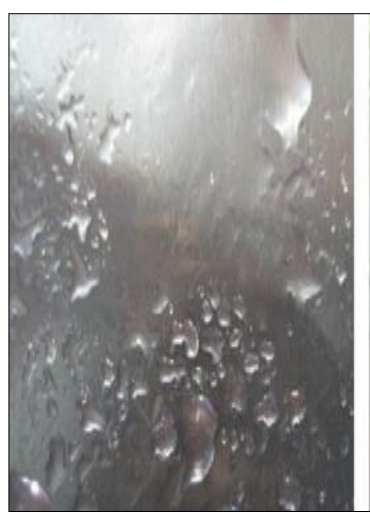

(a)

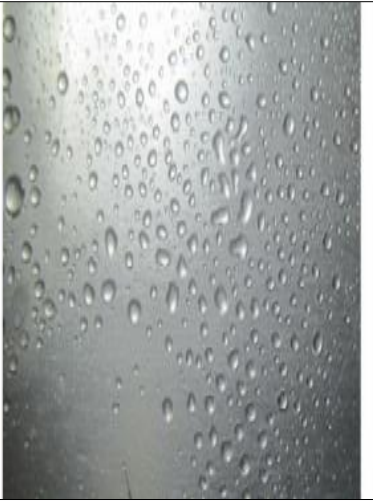

(b)

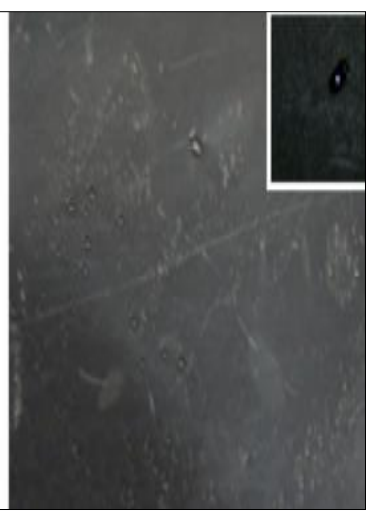

(c)

Fig.1. Water retention on three types of fins: (a) hydrophilic, (b) bare and (c) superhydrophobic.

Wang et al. [6] investigated the effect of the surface type on defrosting time. They compared the efficiency of superhydrophobic, hydrophilic and bare surfaces during defrosting. They concluded that in the case of superhydrophobic surfaces, the defrosting time and energy consumption have decreased compared to hydrophilic and bare surfaces. Jing et al. [7] investigated the phenomena of frosting and defrosting for a rigid superhydrophobic surface and a flexible superhydrophobic surface. The experiments show that the rigid superhydrophobic surface has the advantage of preserving its properties even after several cycles of frosting and defrosting while the flexible superhydrophobic surface did not.

\subsubsection{Off-cycle defrost method}

In off-cycle defrosting methods, the air surrounding the evaporator is used as a heat source. Therefore, this method can be applied for defrosting in environments where the temperature is higher than $1^{\circ} \mathrm{C}$. When the refrigeration system needs to defrost, the compressor stops 
and with it the cooling process. The frost formed on the evaporator starts to melt in time. After the melting process ends, the operation of the refrigeration system is resumed. The advantages of the off-cycle defrost method involve simplicity and low cost [3]. The main disadvantage of the off-cycle defrost method is that it takes a lot of time because the required heat is taken from the surrounding air [8,9].

\subsection{Active defrosting}

The active defrost methods are methods that involve direct energy consumption during the defrost process. The most widely used active defrost methods are: reverse cycle, ultrasonic vibration, hot-gas, electric heating and hot fluid [3].

\subsubsection{Reverse cycle defrosting}

Reverse cycle defrosting involves a four-way valve that allows changing the refrigerant flow path. At the moment when the defrost process is activated, the hot refrigerant coming from the compressors flows through the evaporator (which now acts as a condenser). In the evaporator, the refrigerant condenses and the heat released is used in the defrost process. After the evaporator, the refrigerant flows through a liquid receiver and undergoes an expansion process in an expansion valve before entering the condenser (which acts now as an evaporator). Finally, the refrigerant enters the compressor and the defrost process can continue until the frost formed on the evaporator is removed [10]. The reverse cycle defrost method is very effective leading to a short defrost time [3]. Minglu et al. [11] made a comparison for the defrosting system of an air source heat pump by using the thermal energy storage method and the reverse cycle defrost method. They concluded that in the case of the thermal energy storage method, the defrosting time shortened from $71.4 \%$ to $80.5 \%$ and the energy consumption decreased by $65.1 \%$ to $85.2 \%$ in comparison to the normal reverse cycle defrosting process. Wang et al. [12] experimentally tested two defrosting methods for a refrigeration system utilized in a cold room. The first method was electric heater defrosting and the second was reverse cycle defrost. They concluded that when an electric heater has been used for defrosting, the energy consumption was reduced by $20 \%$. At the same time, the temperature inside the cold storage has been reduced by $7^{\circ} \mathrm{C}$ during the defrosting period. For the reverse cycle method, the time of defrosting has been reduced by $19 \%$ and the energy consumption was reduced by $27.2 \%$. In the same operational condition, the reverse cycle defrost method saves more energy than the electric heater method.

\subsubsection{Ultrasonic vibration}

Ultrasonic vibration is one of the strategies applied for preventing the growth of the frost layer [13]. Cheng et al. studied the effect of low frequencies ranging from 100 to $200 \mathrm{~Hz}$ on the frost layer and found that it had little effect on the frost layer [14]. K. Adachi et al. [15] have studied the effect of $37 \mathrm{kHz}$ high-frequency on an aluminium alloy plate in an environment with air at around $100 \%$ relative humidity and $2{ }^{\circ} \mathrm{C}$. The authors found that high-amplitude ultrasonic vibrations applied to an aluminium alloy plate can inhibit frost accumulation by about $60 \%$ [15]. Tan et al. [16] investigated the effect of using ultrasonic vibration to remove frost from a finned tube evaporator of an air source heat pump. The authors used an ultrasound rating power of $50 \mathrm{~W}$ and a resonance frequency of $40 \mathrm{kHz}$. The result showed that the consumption of energy for the defrosting process was $3.14 \%$ to $5.46 \%$ lower than without intermittent ultrasonic vibration while the heating capability improved by $2.2 \%$ to $9.03 \%$. The coefficient of performance improved by $6.51 \%$ to 15.33 $\%$. Li et al [17] have made an experimental study regarding the influence of $20 \mathrm{kHz}$ ultrasound on frost development for a cold flat surface as shown in Fig. 2. The experiment shows that the frozen water droplets on the surface for which ultrasound effects have been applied became smaller and fragmented than those corresponding to the case without 
ultrasound effects. In the case of ultrasound effects, the freezing drops occupy less than 52 $\%$ in comparison to more than $65 \%$ in the case without ultrasound effect. The frost thickness can be reduce by $75 \%$ during tests when ultrasound effect are applied compared to the case without ultrasound effects. Wang et al. [18] used ultrasonic vibrations to study the effect of frost release from finned evaporators. Experiments showed that ultrasonic vibrations cannot remove the primary ice layer from the fins, but the frost crystals and frost branches forming on the primary ice layer can be easily eliminated. Thus the increase of the frost layer can be suppressed.
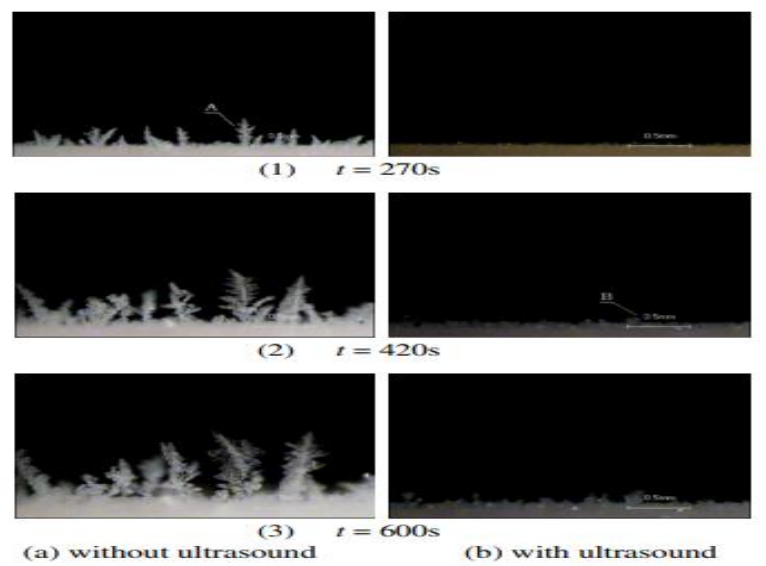

Fig. 2. Side-view of frost formation comparison [17].

\subsubsection{Hot-gas defrost method}

The hot-gas defrost method involves a pipeline connecting the compressor and the evaporator. The compressed refrigerant vapour reaches the evaporator first, then flows to the liquid-gas separator before entering the compressor [19]. During the hot gas defrost process, the high-pressure refrigerant enters the evaporator and warms the tube and thus, the frost is melting [19]. The advantage of hot-gas defrost is its efficiency because the heat comes from inside the evaporator during the defrost process [20]. The energy consumption of the hot-gas defrost method compared to the reverse-cycle method is smaller [20]. The disadvantage of this process is that during the defrost process the refrigerant condenses inside the evaporator and there is a risk of liquid entering the compressor. This risk can be removed by controlling the refrigerant flow in such a way that it can turn back to the vapour state on the suction line, by adding a liquid-gas separator before the compressor or adding a small evaporator before the compressor. Due to auxiliary valves, pipes and equipment the hot-gas defrost can generate supplementary costs.

Liu et al. [21] developed a bypass cycle defrosting technology that makes use of compressor casing thermal storage. The experimental results show that defrosting time was reduced by $65 \%$ to $77 \%$. The overall energy consumption was reduced by $89 \%$ to $92 \%$ and also, the compressor noise was reduced by $18.5 \%$. Cho et al. [22] have studied the performance of the on-off and hot-gas bypass defrosting methods for three evaporators of a cabinet showcase refrigeration system. The results showed that, although it had comparatively more compressor power compared to the on-off cycling, the hot gas defrosting system had a better defrosting capacity and maintained a consistent storage temperature during defrosting. 


\subsubsection{Electric defrosting method}

Electric defrosting methods use electric heating elements mounted in the evaporator. The heating elements are activated during the defrost cycle. Since the heat is applied from outside, only a portion of the heat emitted is used to remove the frost. The rest of the heat is transferred to the air inside the refrigerated space. When the refrigeration system resumes operation after a defrost period, this additional heat must be removed. The advantage of this method is that it is easy to install and control. The disadvantages of this method are: it is expensive and consumes a lot of energy [3, 8, 9].

Yoon et al. [23] focused on improving the defrosting efficiency of a household refrigerator by using three defrost modes. The first mode controls two heaters at the same time; the second mode controls each heater individually and the third mode uses a radiation heater in steps. The results showed that all modes were effective in preventing a temperature rise in the freezer and improving the defrosting efficiency. However, the best performance was obtained by the second mode. The temperature in the refrigerator drops from $11^{\circ} \mathrm{C}$ to $5^{\circ} \mathrm{C}$ at the time of defrosting and improves the defrosting efficiency by $15 \%$. Some researchers such as Melo et al. [24] used three different types of electrical heaters, distributed, chlorine and glass. They discovered that all three types of heaters had the same defrosting efficiency. The glass tube heater had the highest efficiency of $48 \%$. Zhao et al. [25] added an extra heater of $60 \mathrm{~W}$ in the middle of the evaporator besides the original bottom one having $180 \mathrm{~W}$. The aim was to observe the reduction of the temperature rise in the freezer cabinet during the defrosting process. The results showed that adding the heater enhanced the defrost by removing frost on both the lower and upper halves of the evaporator simultaneously. Therefore, the defrost duration was reduced by 3.3 minutes and at the same time, the temperature inside the freezer can be reduced by $1.1{ }^{\circ} \mathrm{C}$ during the defrost cycle. Yin et al. [26] studied a novel defrost method using air bypass circulation and an electric heater for cold storage. The results showed that during defrosting, circulating air was useful for enhancing the defrost speed. Compared with the traditional method (without air bypass), the defrost time of this new method was lowered by $62.1 \%$, defrost energy consumption decreased by $61.0 \%$ and the fluctuation in storage temperature decreased by $70.1 \%$. Furthermore, the efficiency of defrosting raised up to $77.6 \%$ being 2.93 times more efficient than the traditional method.

\subsubsection{Hot fluid defrost method}

The hot fluid defrost method involves the use of a fluid, usually water or brine, which is sprayed on the evaporator. The resulting mixture of water and frost is drained. During the defrost cycle the compressor of the refrigeration system does not work. This defrost method can be applied only if a hot fluid source is available $[8,9]$. In Table 1 , the advantages and disadvantages of the most widely used defrosting methods are summarized.

Table 1.The advantages and disadvantages of defrosting methods

\begin{tabular}{|l|l|l|}
\hline Defrostmethods & \multicolumn{1}{|c|}{ Advantage } & \multicolumn{1}{|c|}{ Disadvantages } \\
\hline Off-cycle defrost & $\begin{array}{l}\text { Simple and economical [17], } \\
\text { low cost, no reconstruction } \\
\text { work [19], low maintenance } \\
\text { costs, it is a safe method, easy } \\
\text { to control }\end{array}$ & $\begin{array}{l}\text { Not relevant in applications } \\
\text { where temperatures are below } \\
\text { freezing [19]. It takes a long } \\
\text { time to melt the frost [20] }\end{array}$ \\
\hline Hot fluid defrost & $\begin{array}{l}\text { Applies hot liquid directly to the } \\
\text { accumulated frost, able to } \\
\text { achieve fast defrost }\end{array}$ & $\begin{array}{l}\text { Limited for application, some } \\
\text { fluid retained on the surface, } \\
\text { not widely investigated or }\end{array}$ \\
\hline
\end{tabular}




\begin{tabular}{|l|l|l|}
\hline & & $\begin{array}{l}\text { applied [19], not recommended } \\
\text { for low-temperature } \\
\text { applications }\end{array}$ \\
\hline Hot - gas & $\begin{array}{l}\text { Efficient in terms of defrosting } \\
\text { time, mostly used in industry } \\
\text { [19], widely used method. }\end{array}$ & $\begin{array}{l}\text { Extremely high working } \\
\text { pressures }\end{array}$ \\
\hline Electric & Easy installation [19] & High energy consumption [19] \\
\hline Reverse cycle & $\begin{array}{l}\text { Time for defrosting shorter than } \\
\text { hot -gas method [19] }\end{array}$ & $\begin{array}{l}\text { Consumes more energy and is } \\
\text { dangerous for use in } \\
\text { refrigerators due to repeated } \\
\text { reversing of the four-way valve, } \\
\text { which can result in refrigerant } \\
\text { leakage }\end{array}$ \\
\hline
\end{tabular}

\subsubsection{Defrosting methods using phase change materials}

There are other methods of defrosting which are using phase change materials (PCMs). The defrosting methods using PCMs are relatively new and are slowly gaining more attention from researchers. Next, Section 3 shortly presents an overview of PCMs and Section 4 presents the application of PCMs in household refrigeration systems and discusses the possibility to use PCMs in defrosting cycles.

\section{Phase change materials}

In recent years, the PCMs have attracted more interest from researchers because of:

- $\quad$ high storage energy capacity;

- $\quad$ low storage volume;

- isothermal behaviour during the charging and discharging phases;

The PCMs have high thermal energy storage capacity and have the ability to release and absorb a big quantity of energy at a constant temperature [27].

\subsection{Classification of phase change materials}

The PCMs can be classified according to the melting temperature into three groups:

- Low-temperature PCMs having a melting temperature below $15^{\circ} \mathrm{C}$.

- Medium temperature PCMs having a melting temperature between $15^{\circ} \mathrm{Cand} 90^{\circ} \mathrm{C}$.

- High-temperature PCMs having a melting point above $90^{\circ} \mathrm{C}$.

Fig. 3 shows the most important applications of PCMs depending on the melting point.

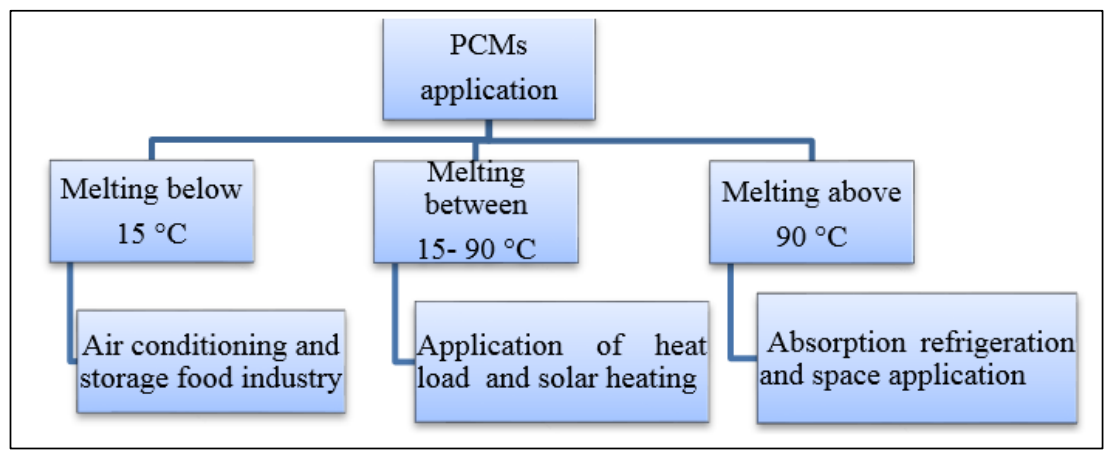


Fig.3.Classification PCMs according to the melting temperature

PCMs can be also classified according to the mode of phase transition: liquid-gas, solidliquid, solid-gas and solid-solid, as shown in Fig 4 [30].

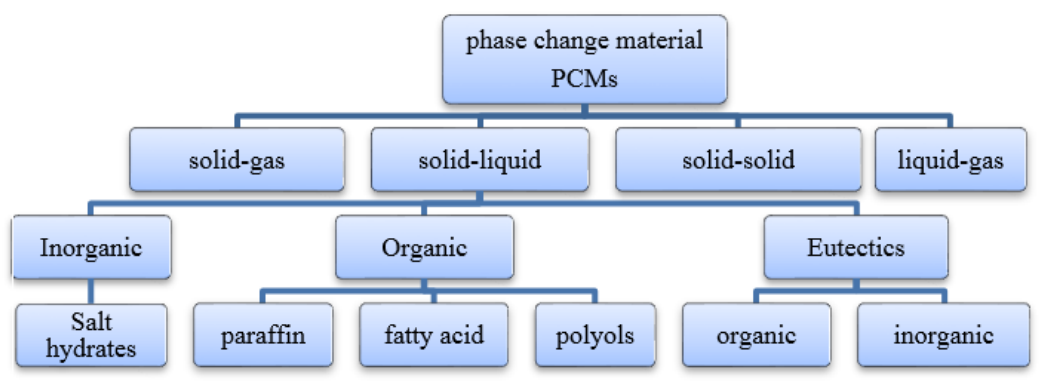

Fig. 4. Classification PCMs according to the mode of transition

\subsection{Inorganic PCMs}

Inorganic PCMSs have a melting temperature ranging from $10^{\circ} \mathrm{C}$ to $900^{\circ} \mathrm{C}$. This type of PCMs is widely used in solar energy applications where the required melting temperature is high. The thermal conductivity of inorganic PCMs is higher than the organic PCMs and so is the density. The main disadvantage of the inorganic PCMs, namely the salt hydrates, is that they exhibit great instability as they lead to water separation during the heating process. Most inorganic salts are not highly flammable.

Salt hydrates are the most studied type of PCM, consisting of water and salt. They have the general formula $\mathrm{AB}_{\mathrm{n}} \mathrm{H}_{2} \mathrm{O}$ and melting temperatures ranging from $15^{\circ} \mathrm{C}$ to $117^{\circ} \mathrm{C}[28$ 30].

The main advantages of salt hydrates are:

- Low cost;

- Availability;

- High melting temperature;

- High thermal conductivity;

- High heat of fusion per unit volume;

- Low volume changes;

- Compatible with plastic;

The main disadvantages of salt hydrates are:

- Separation means the production of additional hydrates or dehydrated salts which tend to decrease the available active volume for heat storage.

- Decrease in heat of fusion more than $73 \%$ for $\mathrm{Na}_{2} \mathrm{SO}_{4} \cdot 10 \mathrm{H}_{2} \mathrm{O}$ after 1000 melt/freeze cycles.

- Salt hydrates show supercooling because the freezing point of other PCMs does not start to crystallize.

- Corrosion appears in metal containers [28-30].

\subsection{Organic PCMs}

Organic PCMs are the most widely used type. This group of PCMs includes the paraffin family, the fatty acids family and polyols. Among these organic PCMs, paraffin is the most common having a melting temperature ranging from $35^{\circ} \mathrm{C}-70^{\circ} \mathrm{C}$. Organic PCMs can store a large amount of energy in a small mass, are chemically and physically stable and are compatible with a wide range of materials. At the same time, the organic PCMs are 
flammable having flashpoints close to $200^{\circ} \mathrm{C}$ which is a value outside their range of application. Organic PCMs display low thermal conductivity [27-30].

Paraffin has the chemical formula $\mathrm{CH}_{3}-\left(\mathrm{CH}_{2}\right)-\mathrm{CH}_{3}$. Its main advantages are:

- Large latent heat during phase change

- No tendency to separate;

- It is chemically stable;

- When exposed to oxygen, it oxidizes slowly;

- There is no change of thermal properties after frequent melting/solidification processes;

- High melting temperatures;

- Non-reactive and safe;

- It is compatible with all-metal containers and easy to integrate into heat storage systems.

The disadvantages of paraffin include:

- low thermal conductivity;

- when changing from solid to liquid, it takes a large volume;

- flammability [28].

\subsection{Fatty acids}

Fatty acids have the chemical formula $\mathrm{CH}_{3}\left(\mathrm{CH}_{2}\right)$ 2nCOOH and they have similar properties as paraffin. The main advantage of fatty acids is their sharper phase transformation. They are more expensive compared with paraffin and are mildly corrosive. However, after 1500 melting/solidification cycles, the fatty acids display thermal stability $[28,30]$.

\subsection{Polyols}

Polyols have the advantage of a small volume change. The main disadvantages involve high phase change temperature, low latent heat and a high cost [30].

\subsection{Eutectics}

They consist of two or more components and have the same melting and solidification temperature. Table 2 presents a list of PCMs and their properties. The corresponding references are also mentioned.

Table 2. The properties and characteristics of PCMs

\begin{tabular}{|c|c|c|c|c|c|}
\hline Ref & $\begin{array}{l}\text { Phase change } \\
\text { materials (PCMs) }\end{array}$ & $\begin{array}{l}\text { Melting } \\
\text { Temperatur } \\
\text { e }\left[{ }^{\circ} \mathrm{C}\right]\end{array}$ & $\begin{array}{l}\text { Heat of } \\
\text { fusion } \\
{[\mathrm{kJ} / \mathrm{kg}]}\end{array}$ & $\begin{array}{l}\text { Thermal } \\
\text { conductivity } \\
{[\mathrm{W} /(\mathrm{m} \mathrm{K})]}\end{array}$ & $\begin{array}{l}\text { Density } \\
{\left[\mathrm{kg} / \mathrm{m}^{3}\right]}\end{array}$ \\
\hline [33] & E21 & 21 & 150 & 0.43 & 1480 \\
\hline [34] & Paraffin & 26 & 82.7 & $0.2(\mathrm{~s}), 0.15(\mathrm{l})$ & $7870(\mathrm{~s}), 750(1)$ \\
\hline [35] & $\mathrm{CaCl} 2 \cdot 6 \mathrm{H}_{2} \mathrm{O}$ & 29.7 & 187.490 & 1.088 & 1710 \\
\hline$[36]$ & $\mathrm{C}-18$ & -18.40 & 306 & $0.5-0.7$ & 1300 \\
\hline [37] & n-octadecane & 27.7 & 243.5 & 0.148 & 777 \\
\hline [38] & $\mathrm{Na} 2 \mathrm{CO} 3.10 \mathrm{H} 2 \mathrm{O}$ & $32-36$ & 247 & - & - \\
\hline [39] & $\mathrm{MgCl} 2.6 \mathrm{H} 2 \mathrm{O}$ & 117 & 168.6 & $\begin{array}{l}0.57\left(1,120^{\circ} \mathrm{C}\right) / 0.694 \\
\left(\mathrm{~s}, 90^{\circ} \mathrm{C}\right)\end{array}$ & $\begin{array}{l}1450\left(\mathrm{~L}, 120^{\circ} \mathrm{C}\right) / 1569 \\
\left(\mathrm{~s}, 20^{\circ} \mathrm{C}\right)\end{array}$ \\
\hline [39] & $\mathrm{Mg}(\mathrm{NO} 3) 2.6 \mathrm{H} 2 \mathrm{O}$ & 89 & 162.8 & $\begin{array}{l}0.49\left(1,95^{\circ} \mathrm{C}\right) / 0.611(\mathrm{~s} \\
\left., 37^{\circ} \mathrm{C}\right)\end{array}$ & $\begin{array}{l}1550\left(1.94^{\circ} \mathrm{C}\right) / 1636(\mathrm{~s}, \\
\left.25^{\circ} \mathrm{C}\right)\end{array}$ \\
\hline [39] & $\mathrm{Ba}(\mathrm{OH}) 2.8 \mathrm{H} 2 \mathrm{O}$ & 48 & 265.7 & $0.653(1) / 1.225(\mathrm{~s})$ & $1937(1) / 2070(\mathrm{~s})$ \\
\hline [39] & Polyglycol E600 & 22 & 127.2 & 0.189 & $1126(1) / 1232(\mathrm{~S})$ \\
\hline
\end{tabular}




\begin{tabular}{|l|l|l|l|l|l|}
\hline$[39]$ & Palmitic acid & 64 & 185.4 & 0.162 & $850(\mathrm{l}) / 989(\mathrm{~S})$ \\
\hline$[39]$ & Capric acid & 32 & 152.7 & $0.153(\mathrm{l})$ & $878(\mathrm{l}) / 1004(\mathrm{~S})$ \\
\hline$[39]$ & Caprylic acid & 16 & 148.5 & 0.149 & $901(\mathrm{l}) / 981(\mathrm{~S})$ \\
\hline$[40]$ & $\begin{array}{l}\text { H20(salt } \\
\text { hydrates })\end{array}$ & 0 & 333 & $0.6\left(20^{\circ} \mathrm{C}\right) / 2.2(\mathrm{~s})$ & $917\left(0^{\circ} \mathrm{C}\right) / 998\left(20^{\circ} \mathrm{C}\right)$ \\
\hline$[40]$ & KF.4H20 & 18.5 & 231 & 0.4 & $1455(18 \mathrm{c}) / 1447\left(20^{\circ} \mathrm{C}\right.$ \\
& & & & & $1485(\mathrm{~s})$ \\
\hline$[40]$ & Na2S04.10H20 & 32.4 & 254 & $1.93(\mathrm{~s})$ & $1520(\mathrm{~s}) / 1442(\mathrm{l})$ \\
\hline$[40]$ & Na2Hp04.12H2 & 35 & 281 & $1.7(\mathrm{~s}) / 1.95(\mathrm{l})$ & $2065\left(14{ }^{\circ} \mathrm{C}\right)$ \\
\hline$[40]$ & Zn(N03)2.6H2 & 36.4 & 147 & $1.34(\mathrm{~s}) / 2.26(1)$ & $1730(\mathrm{~s}) / 1670(\mathrm{l})$ \\
\hline$[40]$ & Na2S203.5H20 & 48 & 201 & $1.46(\mathrm{~s}) / 2.39(1)$ & $2180(\mathrm{~s})$ \\
\hline$[40]$ & Ba(0H)2.8H20 & 78 & 267 & $1.17(\mathrm{~s})$ & $780(\mathrm{l}) / 860(\mathrm{~s})$ \\
\hline$[41]$ & Wax(p116) & 49 & 210 & $0.24(\mathrm{~s}) / 0.15(\mathrm{l})$ & $1500(\mathrm{l}) / 1680(\mathrm{~s})$ \\
\hline$[41]$ & Calcium chloride & 28 & 200 & $0.626(\mathrm{~s}) / 0.45(\mathrm{l})$ & $880(\mathrm{sol}) / 770(1)$ \\
\hline$[42]$ & IGI 1230A & 54.2 & 278.2 & $0.25(\mathrm{~s}) / 0.135(\mathrm{l})$ & $871(\mathrm{l})$ \\
\hline$[43]$ & Oleic acid & 13 & 75.5 & $0.103(\mathrm{l})$ & $1004(\mathrm{~s}) / 878(\mathrm{l})$ \\
\hline$[43]$ & Capric acid & 32 & 153 & $0.153(\mathrm{l})$ & $1007(\mathrm{~s}) / 965(\mathrm{l})$ \\
\hline$[43]$ & Lauric acid & 44 & 178 & $0.147(\mathrm{l})$ & $989(\mathrm{~s}) / 850(\mathrm{l})$ \\
\hline$[43]$ & Palmitic acid & 64 & 185 & $0.162(\mathrm{l})$ & $965(\mathrm{~s}) / 848(\mathrm{l})$ \\
\hline$[43]$ & Stearic acid & 69 & 202 & $0.172(\mathrm{l})$ & \\
\hline
\end{tabular}

\section{Application of PCMs in household refrigeration systems}

Generally, in the case of household refrigerators, PCMs are used in order to improve their performance. In literature, work has been conducted to improve the coefficient of performance (COP) by using PCMs at the condenser level, evaporator level and inside the cold storage space [31]. In this regard, Table 3 presents a part of the literature which has as a subject the use of PCMs in household refrigerators. Table 3 covers the time period from 2008 to 2020.

Table 3. Literature regarding the use of PCMs in household refrigerators

\begin{tabular}{|c|c|c|c|}
\hline Author & Main conclusion & $\begin{array}{l}\text { Components } \\
\text { where PCMs } \\
\text { are used }\end{array}$ & Year \\
\hline Azzouz et al [44] & $\begin{array}{l}\text { The use of PCMs increases the energy } \\
\text { efficiency and leads to enhanced heat transfer } \\
\text { from the evaporator }\end{array}$ & $\begin{array}{l}\text { The outer side } \\
\text { of the } \\
\text { evaporator }\end{array}$ & 2008 \\
\hline Azzouz et al [45] & $\begin{array}{l}\text { Adding PCMs shows a significant increase in } \\
\text { efficiency compared to a conventional } \\
\text { system }\end{array}$ & $\begin{array}{l}\text { The backside } \\
\text { of the } \\
\text { evaporator }\end{array}$ & 2009 \\
\hline $\begin{array}{l}\text { Long Cheng } \\
\text { et al [46] }\end{array}$ & $\begin{array}{l}\text { Adding PCMs results in a lower condensation } \\
\text { temperature, a higher evaporating temperature } \\
\text { and much larger subcooling, as well as a } 12 \% \\
\text { improvement in performance. }\end{array}$ & Condenser & 2011 \\
\hline $\begin{array}{l}\text { Khan and Afroz et al } \\
{[47]}\end{array}$ & $\begin{array}{l}\text { PCMs, decrease the fluctuation of the cabinet } \\
\text { temperature. }\end{array}$ & Evaporator & 2014 \\
\hline $\begin{array}{l}\text { Khan and Afroz et al } \\
{[48]}\end{array}$ & $\begin{array}{l}\text { The effect of PCMs in compressor on-off } \\
\text { cycle has been studied. The authors found that } \\
\text { the number of compressors on-off cycles with } \\
\text { PCMs is } 5 \% \text { to } 30 \% \text { lower. The efficiency } \\
\text { increases and the temperature fluctuation } \\
\text { inside the cabinet decreases. }\end{array}$ & Evaporator & 2015 \\
\hline Sonnenrein et al [49] & $\begin{array}{l}\text { Water, paraffin or copolymer compound has } \\
\text { been used as PCM. The energy consumption } \\
\text { has been reduced and the temperature lowered } \\
\text { from } 4^{\circ} \mathrm{C} \text { to } 0.5^{\circ} \mathrm{C} \text {. }\end{array}$ & Evaporator & 2015 \\
\hline
\end{tabular}




\begin{tabular}{|c|c|c|c|}
\hline Yusufoglu et al[50] & $\begin{array}{l}\text { PCMs have been used to reduce the } \\
\text { compressor on/off time, resulting in a } 9.4 \% \\
\text { energy saving }\end{array}$ & Evaporator & 2015 \\
\hline Reddy et al[51] & $\begin{array}{l}\text { The authors used PCMs to cover the } \\
\text { evaporator and the results show that the } \\
\text { cooling effect inside the chamber increased. } \\
\text { COP also increased from } 3.29 \text { to } 3.5 \text {. }\end{array}$ & Evaporator & 2016 \\
\hline Long Cheng et al [52] & $\begin{array}{l}\text { PCMs have been used in condenser and } \\
\text { evaporator and the result shows electrical } \\
\text { consumption savings between } 28 \% \text { and } 32 \\
\% \text {. }\end{array}$ & $\begin{array}{l}\text { Condenser- } \\
\text { evaporator }\end{array}$ & 2017 \\
\hline Bakhshipour et al [53] & $\begin{array}{l}\text { The authors point out that using } \mathrm{PCMs} \\
\text { increases the convection procedure and } \\
\text { results in a } 9.58 \% \text { improvement of the COP. }\end{array}$ & $\begin{array}{l}\text { PCMs Heat } \\
\text { exchanger after } \\
\text { the condenser }\end{array}$ & 2017 \\
\hline Elarem et al [54] & $\begin{array}{l}\text { The experimental results indicate that energy } \\
\text { consumption decreased by } 12 \% \text { and the COP } \\
\text { increased by } 8 \% \text {, compared to the refrigerator } \\
\text { without PCMs. }\end{array}$ & Evaporator & 2017 \\
\hline Liu et al [55] & $\begin{array}{l}\text { The refrigerator's energy consumption, with } \\
\text { PCMs, decreased by } 18.6 \% \text {, and the } \\
\text { compressor ON-time ratio was reduced by } \\
13.6 \% \text {. }\end{array}$ & $\begin{array}{l}\text { Evaporator } \\
\text { (free frost) }\end{array}$ & 2017 \\
\hline $\begin{array}{l}\text { Dandotiya and Banker } \\
\text { et al [56] }\end{array}$ & $\begin{array}{l}\text { The COP in the case of the PCMs-based } \\
\text { condenser was } 28 \% \text { higher and the energy } \\
\text { consumption was } 15 \% \text { lower. }\end{array}$ & Condenser & 2017 \\
\hline Liu et al [21] & $\begin{array}{l}\text { The authors proposed the use of a compressor } \\
\text { casing thermal storage using PCMs for } \\
\text { defrosting purposes. The results show that } \\
\text { defrosting time can be reduced by } 65 \% \text { to } 77 \\
\% \text {, energy consumption can be reduced by } 89 \\
\% \text { to } 92 \% \text { and also, the compressor operating } \\
\text { noise level can be reduced by } 18.5 \% \text {. }\end{array}$ & Compressor & 2017 \\
\hline Liu et al [57] & $\begin{array}{l}\text { The authors used a heat exchanger after the } \\
\text { compressor for four different types of PCMs } \\
\text { and modes of operation. As a result, } \\
\text { defrosting speed was increased by } 50 \% \\
\text { compared to the initial electric heating, while } \\
\text { defrosting electric energy consumption was } \\
\text { decreased by approximately } 71 \% \text {. }\end{array}$ & $\begin{array}{l}\text { After } \\
\text { compressor }\end{array}$ & 2017 \\
\hline $\begin{array}{ll}\text { Zarajabad } & \text { and } \\
\text { Ahmadi et al[58] }\end{array}$ & $\begin{array}{l}\text { The authors have used PCMs and fins. They } \\
\text { noticed that the compressor's energy } \\
\text { consumption decreased by } 17.4 \% \text {. }\end{array}$ & Evaporator & 2018 \\
\hline $\begin{array}{l}\text { Tikudave and hole et } \\
\text { al[46] }\end{array}$ & $\begin{array}{l}\text { They used the heat storage condensers } \\
\text { between the condenser and evaporator in the } \\
\text { household refrigerator. The results show: the } \\
\text { condensation temperature is lower, the } \\
\text { temperature inside the cabinet is more stable, } \\
\text { the on-time was improved, the COP increased } \\
\text { by } 21.5 \% \text { and the energy efficiency increased } \\
\text { by } 15 \% \text {. }\end{array}$ & Evaporator & 2018 \\
\hline Pirvaram et al [59] & $\begin{array}{l}\text { The authors used two eutectic PCMs and the } \\
\text { results show that the compressor work time } \\
\text { percentage was reduced from } 32.7 \% \text { to } 27.6 \\
\% \text {. The energy consumption was reduced by } \\
13 \% \text { when using one PCM and by } 8 \% \text { by } \\
\text { using two PCMs. }\end{array}$ & Condenser & 2019 \\
\hline
\end{tabular}




\begin{tabular}{|l|l|l|l|}
\hline Maiorino et al [60] & $\begin{array}{l}\text { The use PCMs determined a noticeable } \\
\text { decrease of the temperature gradient within } \\
\text { the cabinet and extended the OFF time of the } \\
\text { compressor. }\end{array}$ & 2019 \\
\hline $\begin{array}{l}\text { Abdolmaleki et al } \\
{[61]}\end{array}$ & $\begin{array}{l}\text { The energy consumption with PCMs was } \\
\text { reduced by } 8.37 \% .\end{array}$ & Evaporator & 2020 \\
\hline
\end{tabular}

As it can be noticed from Table 3, PCMs have attracted attention as a solution to increase the efficiency of household refrigerators. As a remark, in the case of household refrigerators, the efficiency can be further improved by using PCMs during the defrost cycles. This is a topic that requires further investigation.

\section{Conclusion}

The paper presents a literature review regarding the defrost methods for vapour compression refrigeration systems and heat pumps. The literature review covers the period between 2008 and 2020. A number of 61 papers have been studied. One specialized in refrigeration systems and heat pumps can notice that the available scientific literature having as a topic defrost methods is scarce compared to other topics from refrigeration/heat pump technology like new types of refrigerants or efficiency enhancement.

There are two main types of defrosting methods: passive and active. Passive methods involve surface coating and off-cycle. The active defrost methods involve reverse cycle, ultrasonic vibration, hot-gas defrost, electric heating and hot fluid. Among these methods, surface coating and ultrasonic vibration are the most recent ones proposed in literature while the other methods could be classified as well know and widely used methods.

The present work shows that defrosting methods are an important source of direct energy consumption, except for the surface coating and off-cycle defrost. Reducing the energy consumption during the defrost cycle will lead to the higher efficiency of the refrigeration/heat pump system. In this regard, recently, phase change materials have been used in household refrigerators to improve their efficiency. The number of papers regarding this subject is constantly increasing. Related to phase change materials, the most recent work involves their use in the defrost cycles of the refrigeration systems. This is a topic that needs further investigation and is a subject of interest as it can lead to lower energy consumption during defrost cycles. Defrost cycles using phase change materials could be applied to both household and industrial refrigeration systems. In the next years, at least in Europe, the standards regarding household refrigerator energy consumption will become more strict. In this context and based on the present work, the research direction regarding the use of PCMs in defrost cycles can be highlighted.

\section{References}

[1] M. Qu, L. Xia, S. Deng, Y. Jiang, Appl. Energy 91,122-129 (2012)

[2] W. Su, W. Li, X. Zhang, Energy Convers. Manag. 148, 1157-1169 (2017)

[3] M. Amer, C.C. Wang, Renew. Sustain. Energy Rev. 73, 53-74 (2017)

[4] F. Wang, C. Liang, M. Yang, X. Zhang, Exp. Therm. Fluid Sci. 61, 113-120(2015)

[5] L. Cai, R. Wang, P. Hou, X. Zhang, Energy Build. 43, 1159-1163(2011)

[6] F. Wang, C. Liang, M. Yang, X. Zhang, Appl. Therm. Eng. 113, 229-237 (2017)

[7] T. Jing, Y. Kim, S. Lee, D. Kim, J. Kim, W. Hwang, Appl. Surf. Sci. 276, 37-42 (2013)

[8] K. Nawaz, A. Elatar, B. Fricke, A Critical Literature Review of Defrost Technologies for Heat Pumps and Refrigeration Systems, (US DEPARTMENT OF ENERGY, 2018)

[9] M. Song, S. Deng, C. Dang, N. Mao, Z. Wang, Appl. Energy 211,1150-1170 
(2018)

[10] J. Shen, Z. Qian, Z. Xing, Y. Yu, M. Ge, Energy Procedia 160, 491-498,(2019)

[11] M. Qu, T. Li, S. Deng, Y. Fan, Z. Li, Appl. Therm. Eng. 121, 728-736 (2017)

[12] D. Wang, J. Jiang, L. Tao, Z. Kou, L. Yao, Appl. Therm. Eng. 127, 1267-1273 (2017)

[13] H. Tan, X. Zhang, L. Zhang, T. Tao, G. Xu, Appl. Therm. Eng. 153, 113-127 (2019)

[14] C.H. Cheng, C.C. Shiu, Int. J. Refrig. 26, 69-78 (2003)

[15] K. Adachi, K. Saiki, H. Sato, T. Ito, Japanese J. Appl. Physics, Part 1 Regul. Pap. Short Notes Rev. Pap. 42, 682-685 (2003)

[16] H. Tan, G. Xu, T. Tao, X. Sun, W. Yao, Appl. Energy 158, 220-232,(2015)

[17] D. Li, Z. Chen, M. Shi, Exp. Therm. Fluid Sci. 34, 1247-1252,(2010)

[18] D. Wang, T. Tao, G. Xu, A. Luo, S. Kang, Exp. Therm. Fluid Sci. 36, 1-11(2012)

[19] N. Hoffenbecker, S.A. Klein, D.T. Reindl, Int. J. Refrig. 28, 605-615(2005)

[20] J.H. Rainwater, ASHRAE J. 51 38-51 (2009)

[21] Z. Liu, F. Zhao, L. Zhang, R. Zhang, M. Yuan, Y. Chi, Appl. Therm. Eng. 130, 1215-1223 (2018)

[22] H. Cho, Y. Kim, I. Jang, Energy 30, 1915-1930 (2005)

[23] Y. Yoon, H. Jeong, K.S. Lee, Energy Convers. Manag. 157, 511-516 (2018)

[24] C. Melo, F.T. Knabben, P. V. Pereira, Appl. Therm. Eng. 51, 239-245 (2013)

[25] R. Zhao, D. Huang, X. Peng, H. Yang, Int. J. Refrig. 99, 186-193 (2019)

[26] H.J. Yin, Z. Yang, A.Q. Chen, N. Zhang, Energy 37, 623-631 (2012)

[27] A.F. Regin, S.C. Solanki, J.S. Saini, Renew. Sustain. Energy Rev. 12, 2438 2458(2008)

[28] S.D. Sharma, K. Sagara, Int. J. Green Energy 2, 1-56 (2005)

[29] J. Vadhera, A. Sura, G. Nandan, G. Dwivedi, Mater. Today Proc. 5, 34113417(2018)

[30] S.F. Li, Z. hua Liu, X.J. Wang, Appl. Energy 255, 113667(2019)

[31] K. Du, J. Calautit, Z. Wang, Y. Wu, H. Liu, Appl. Energy 220, 242-273(2018)

[32] J. Shen, Z. Qian, Z. Xing, Y. Yu, M. Ge, Energy Procedia 160, 491-498 (2019)

[33] F. Wang, G. Maidment, J. Missenden, R. Tozer, Appl. Therm. Eng. 27, 29022910(2007)

[34] V. Antony Aroul Raj, R. Velraj, Int. J. Therm. Sci. 50, 1573-1582 (2011)

[35] A.H. Mosaffa, F. Talati, H. Basirat Tabrizi, M.A. Rosen, Energy Build. 49, 356$361(2012)$

[36] E. Oró, L. Miró, M.M. Farid, L.F. Cabeza, Int. J. Refrig. 35, 984-991 (2012)

[37] A. Ehsan, H. Singh, M. Saqlain, G. Farid, Sci.Int.(Lahore). 26, 1435-1438(2014)

[38] M. Jaafer, A. Alatabe, Int. J. Sci. Res. Sci. Eng. Technol. 4, 93-98(2018)

[39] M.M. Farid, A.M. Khudhair, S.A.K. Razack, S. Al-Hallaj, Energy Convers. Manag. 45, 1597-1615 (2004)

[40] A. Abhat, Sol. Energy 30, 313-332 (1983)

[41] H. El-Dessouky, F. Al-Juwayhel, Energy Convers. Manag. 38, 601-617 (1997)

[42] R.J. Warzoha, R.M. Weigand, A.S. Fleischer, Appl. Energy 137, 716-725(2015)

[43] H. Ge, H. Li, S. Mei, J. Liu, Renew. Sustain. Energy Rev. 2, 1331-346 (2013)

[44] K. Azzouz, D. Leducq, D. Gobin, Int. J. Refrig. 31, 892-901 (2008)

[45] K. Azzouz, D. Leducq, D. Gobin, Int. J. Refrig. 32, 1634-1644 (2009)

[46] W.L. Cheng, B.J. Mei, Y.N. Liu, Y.H. Huang, X.D. Yuan, Energy 36, 5797-5804 (2011)

[47] H.M.M. Afroz,Int. J. Recent adv. Mech. Eng. (IJMECH)3, 43-52(2014)

[48] M. Imran Hossen Khan, H.M.M. Afroz, Sci. Technol. Built Environ. 21, 462-468 (2015) 
[49] G. Sonnenrein, E. Baumhögger, A. Elsner, K. Fieback, A. Morbach, A. Paul, J. Vrabec, Int. J. Refrig. 60, 166-173 (2015)

[50] Y. Yusufoglu, T. Apaydin, S. Yilmaz, H.O. Paksoy, Int. J. Refrig. 57, 173185(2015)

[51] R. Rahman, IOSR J. Mech. Civ. Eng. 10, 08-16(2013)

[52] W. long Cheng, M. Ding, X. dong Yuan, B.C. Han, Energy Convers. Manag. 132, 180-188 (2017)

[53] S. Bakhshipour, M.S. Valipour, Y. Pahamli, Int. J. Refrig. 83, 1-13 (2017)

[54] R. Elarem, S. Mellouli, E. Abhilash, A. Jemni, Appl. Therm. Eng. 125, 13201333(2017)

[55] Z. Liu, D. Zhao, Q. Wang, Y. Chi, L. Zhang, Int. J. Refrig. 79,130-142 (2017)

[56] D. Dandotiya, N.D. Banker, Int. J. Air-Conditioning Refrig. 25, 1-9 (2017)

[57] Z. Liu, A. Li, Q. Wang, Y. Chi, L. Zhang, Appl. Therm. Eng. 118,256-265 (2017)

[58] O. Ghahramani Zarajabad, R. Ahmadi, Therm. Sci. Eng. Prog. 7,115-124 (2018)

[59] A. Pirvaram, S.M. Sadrameli, L. Abdolmaleki, Energy. 181, 321-330 (2019)

[60] A. Maiorino, M.G. Del Duca, A. Mota-Babiloni, A. Greco, C. Aprea, Int. J. Refrig. 100, 255-264 (2019)

[61] L. Abdolmaleki, S.M. Sadrameli, A. Pirvaram, Renew. Energy 145, 233-241 (2020) 